\title{
Characterisation of the mobility on isoelectric focusing of individual proteins in CSF and serum by immunofixation
}

\author{
MARI A ASUNTA LAURENZI AND HANS LINK \\ From the Department of Neurology, University Hospital, Linköping, Sweden
}

SUMMARY The mobility of 17 different proteins in CSF and serum on isoelectric focusing was investigated by subsequent immunofixation using monospecific antisera. Individual proteins yielded identical, often complex band patterns in normal CSF and serum, except transferrin

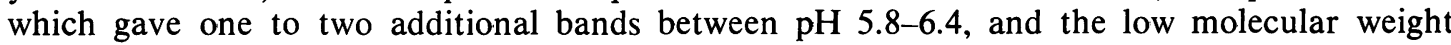

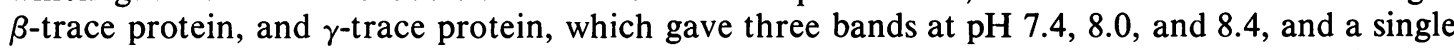
band at $\mathrm{pH} 9.5$, respectively, on investigation of CSF but not serum. Polyclonal IgG migrated as multiple bands between $\mathrm{pH}$ 4.7-8.6. Oligoclonal IgG in CSF in multiple sclerosis and neurosyphilis migrated between $\mathrm{pH}$ 8.6-9.5 and was easily discriminated from other proteins.

Isoelectric focusing on thin layer polyacrylamide gel has been proposed for analytical investigation of cerebrospinal fluid (CSF) proteins in degenerative diseases of the central nervous system (CNS) (Kjellin and Stibler, 1974, 1975; Stibler and Kjellin, 1976) and for demonstration of oligoclonal immunoglobulin (Ig) bands in for example, multiple sclerosis (Delmotte, 1971, 1975; Kjellin and Vesterberg, 1972, 1974; Latner, 1973; Delmotte and Gonsette, 1977; Kjellin and Sidén, 1977). The use of isoelectric focusing in this context necessitates the definition of the mobility of normally occurring proteins in CSF and serum, as well as the mobility of IgG in the patient with multiple sclerosis.

In the present study an immunofixation procedure was used for determination of the mobility on isoelectric focusing of albumin, prealbumin, $\alpha_{1}$-antitrypsin, $\alpha_{2}$-macroglobulin, transferrin, haptoglobin, $\beta_{2}$-microglobulin, caeruloplasmin, orosomucoid, complement factors 3 and $4\left(C_{3}, C_{4}\right)$, $\mathrm{C}$-reactive protein, IgG, IgA, IgM, $\beta$-trace protein, and $\gamma$-trace protein.

\section{Materials}

Individual proteins were identified in the patterns obtained at isoelectric focusing of pools of normal

Address for reprint requests: Professor Hans Link, Department of Neurology, Linköping University, S-581 85 Linköping, Sweden. Accepted 19 October 1978 serum and pools of normal CSF, each pool containing identical amounts of material from 1 different individuals. These were neurologica $\$$ patients with a normal CSF cell count, a normap blood-brain barrier as determined by the CSF serum albumin ratio (Link and Tibbling, 1977) normal values of the CSF/IgG index determined according to Tibbling et al. (1977) $(<0.70), \mathrm{CSF} /$ $\operatorname{IgA}$ index $(<0.62)$ and $\mathrm{CSF} / \operatorname{IgM}$ index $(<1.0)$ (Frydén et al., 1978) normal serum values of IgG, $\operatorname{IgA}$, and $\operatorname{IgM}$, and normal findings at agarose gel electrophoresis of CSF and serum. Individual proteins were also identified in specimens of CSF and serum from normal individuals, from multiple sclerosis patients, and from one patient with neurosyphilis. In addition, IgM was identified in CSF and serum from one patient with Mollaret's chronic meningitis.

All antisera were purchased from Dakopatts (Copenhagen, Denmark), except the antisera against $\beta$-trace protein and $\gamma$-trace protein, which were a gift from Dr J-E. Olsson, Department of Neurology, University of Lund, Sweden. The monospecificity of the antisera was tested by immunolectrophoresis.

\section{Methods}

ISOELECTRIC FOCUSING

This was carried out on LKB Ampholine ready prepared thin layer polyacrylamide gels (PAG 
plates, LKB, Stockholm, Sweden) according to the manufacturers' instructions. The $\mathrm{pH}$ range was 3.5-9.5. The anode-electrode solution consisted of $1 \mathrm{M} \mathrm{H}_{3} \mathrm{PO}_{4}$, the cathode-electrode solution of $1 \mathrm{M} \mathrm{NaOH}$. For routine separation, CSF was concentrated by ultrafiltration in collodion bags (Sartorius Membran Filter, Göttingen, West Germany) to an IgG level of 3-4 g/l. Serum was diluted with physiological saline to the corresponding IgG concentration. Samples of CSF and serum from the same patient were always run side by side on the same plate: $15 \mu 1$ of concentrated CSF and of diluted serum, corresponding to $60-80 \mu \mathrm{g}$ of IgG, were absorbed on filter paper pieces $(10 \times 5 \mathrm{~mm})$ which were applied on the gel at a $\mathrm{pH}$ interval between 6.2-6.4. Pooled blood donor serum, serum IgG (Kabi, Stockholm, Sweden) with a concentration of $4 \mathrm{~g} / 1$, and carboxyhaemoglobin were run as references on every plate. The separation was started at about $200 \mathrm{~V}$ and $50 \mathrm{~mA}$, and the voltage was increased every 10 minutes until, after one hour, about $1200 \mathrm{~V}$ and $18 \mathrm{~mA}$ were reached. Separation was continued at this voltage for an additional 30 minutes until the carboxyhaemoglobin had formed several sharp bands. The electrofocusing apparatus was connected with a cooling system to allow separation at about $8^{\circ} \mathrm{C}$. After 90 minutes altogether the $\mathrm{pH}$ gradient between the anode and the cathode was measured by surface electrode (type LOT 40330 M8, Ingold, Zürich, Switzerland) at the temperature of the experiment-that is, $8^{\circ} \mathrm{C}$. Thereafter, isoelectric focusing was carried out for an additional 10 minutes. The proteins were then fixed, stained, and dried according to the manufacturers' instructions.

\section{IMMUNOFIXATION}

For identification of the migration of individual proteins on isoelectric focusing, immunofixation was carried out according to Arnaud et al. (1977) with slight modification. For the initial separation on isoelectric focusing, CSF was concentrated and serum diluted to obtain a concentration of the individual protein to be identified of 1-2 g/l. If possible, $20-40 \mu \mathrm{g}$ of the protein to be identified was thus applied. Because of the low concentrations of some proteins in CSF, up to $30 \mu 1$ of concentrated CSF was sometimes applied. Too high a protein content had to be avoided because excess of protein in relation to antiserum in the subsequent immunofixation procedure causes the immunoprecipitate to dissolve. After isoelectric focusing, the temperature of the polyacrylamide gel was immediately kept constant at $8^{\circ} \mathrm{C}$ in order to prevent protein diffusion. Cellulose acetate strips (Sepharose III, Gelman Instrument Company, Ann Arbor, Michigan, USA) were dipped in the corresponding antiserum and applied to the gel surface. The gel plate was incubated for one hour in a moist chamber at room temperature, and then two glass plates were put on the gel for $30 \mathrm{~min}$ to apply uniform pressure. Thereafter, the strips were removed carefully, and the strips and the gel plate were washed separately in two litres of physiological saline overnight. The strips and the gel were stained with Coomassie Brilliant Blue (R 250) in ethanol-water-acetic acid $(3: 9: 1)$, destained in ethanol-water-acetic acid $(3: 9: 1)$, and stored in preserving solution consisting of glycerol in the destaining solution $(1: 10)$. The patterns obtained from development of immune complexes in the cellulose acetate strips were compared with those in the gel.

\section{Results}

The mobility of individual proteins on isoelectric focusing of normal CSF and serum are shown in the Table. It is obvious that most proteins migrated in the form of two or more bands, and that there is considerable overlapping regarding the mobility of bands corresponding to individual proteins. For most proteins the number of bands and the mobility of the bands were identical in CSF and serum. Thus, IgA migrated as six to 13 bands between $\mathrm{pH}$ 4.9-6.1 (Fig. 1) and no differences were observed regarding the mobility of IgA in CSF compared with the corresponding serum, but the number of bands differed between different CSF and serum samples and pools.

Table Localisation of proteins in CSF and serum on isoelectric focusing

\begin{tabular}{lll}
\hline Protein & $p H$ interval & $\begin{array}{l}\text { Number of } \\
\text { bands }\end{array}$ \\
\hline Albumin & $4.8-5.2$ & 1 broad band \\
Prealbumin & $5.0-5.4$ & $3-4$ \\
$\alpha_{1}$-antitrypsin & $4.7-5.3$ & $4-5$ \\
Caeruloplasmin & $4.9-5.2$ & 3 \\
Orosomucoid & $4.0-4.4$ & 3 \\
Haptoglobin & $4.7-5.0$ & $2-3$, \\
Serum-transferrin & $5.2-5.7$ & or 1 broad band \\
CSF-transferrin & $5.2-6.4$ & $5-6$ \\
$\alpha_{2}$-macroglobulin & $5.8-6.0$ & $7-8$ \\
C, & $5.6-5.8$ & $4-5$ \\
C & $5.7-5.9$ & $2-3$ \\
$\beta_{2}$-microglobulin & 6.1 & 2 \\
C-reactive protein & -1 & 1 \\
IgG & $4.7-8.6$ & 0 \\
IgA & $4.9-6.1$ & $>15$ \\
IgM & $-13-13$ \\
CSF- $\beta$-trace protein & $7.4-7.5$ & 0 \\
& 8.0 & 1 \\
CSF- $\gamma$-trace protein & 8.4 & 1 \\
\hline & $9.5>9.5$ & 1 \\
\hline
\end{tabular}




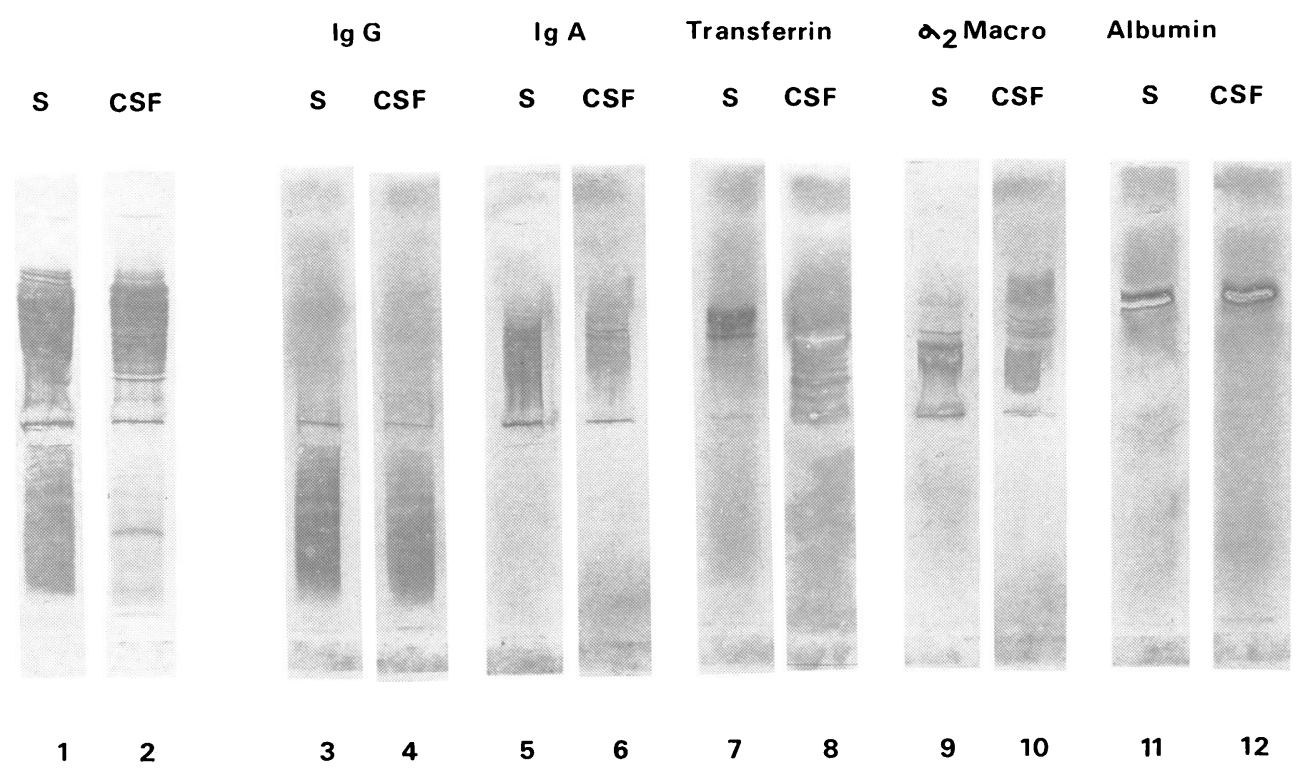

Fig. 1 Patterns on isoelectric focusing of pools of normal serum (1) and of normal CSF (2), and patterns from isoelectric focusing and subsequent immunofixation of the same pool of normal serum and of normal $C S F$, using specific antisera against $\lg G(3-4), \lg A(5-6)$, transferrin $(7-8), \alpha_{-}-$macroglobulin $(9-10)$, and albumin (11-12).

For several proteins, especially haptoglobin in $\mathrm{CSF}$, and $\mathrm{C}_{3}$ and $\mathrm{C}_{4}$ in both CSF and serum, it was difficult to characterise the mobility on isoelectric focusing by the method used. However. in the patient with Mollaret's chronic meningitis, who also had severe blood-brain barrier damage, it was possible to define the mobility of haptoglobin, $\mathrm{C}_{3}$, and $\mathrm{C}_{4}$. The results regarding mobility of these three proteins in this patient confirmed the somewhat uncertain findings obtained at investigation of their mobility in other specimens.

$C$-reactive protein was not demonstrable in serum nor in CSF. The same was true for IgM in CSF and serum from normal subjects and multiple sclerosis patients. In CSF from the neurosyphilis patient, IgM migrated as two faint, indefinite bands, one at pH 5.2 and one at pH 5.4. This patient displayed oligoclonal IgM demonstrable by immunofixation after agarose gel electrophoresis, in CSF but not in serum. Isoelectric focusing of serum from this patient did not yield any demonstrable IgM bands.

For some proteins, there were differences in the occurrence or mobility of bands in CSF compared with serum. Transferrin in serum and CSF yielded the same band pattern between pH 5.2-5.7. However, 2-3 additional bands were found in the CSF but not in serum between pH 5.7-6.4 (Fig. 1).

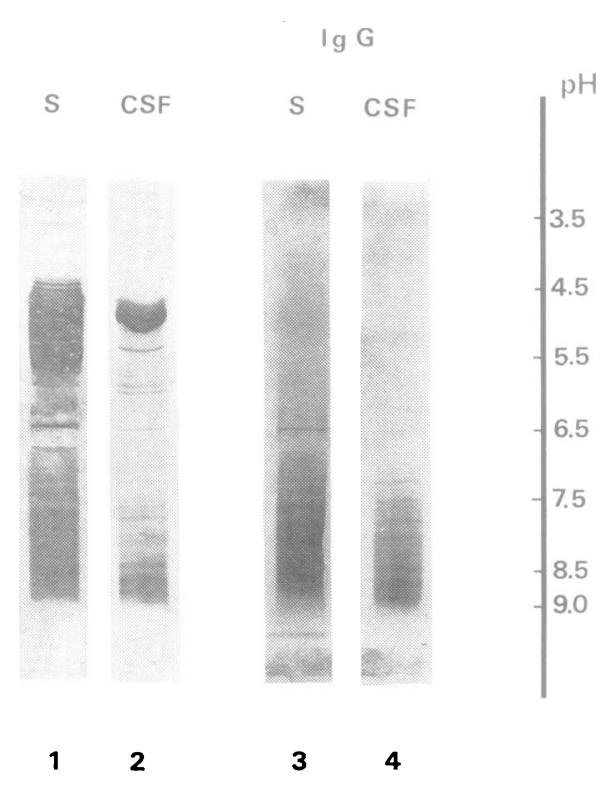

Fig. 2 Patterns on isoelectric focusing of serum (I) and CSF (2) from one patient with multiple sclerosis, and patterns from isoelectric focusing and subsequent immunofixation of the same serum (3) and CSF (4) using specific antiserum against $\lg G$. 
IgG migrated in the form of more than 15 bands between pH 4.7-8.6 (Fig. 1). The bands differed in number and mobility in different normal samples and pools of CSF and serum. The lowest $\mathrm{pH}$ at which IgG bands were demonstrable varied between 4.7-5.5. A constant feature, however, was that no IgG bands were demonstrable at a pH higher than 8.6 in CSF or serum.

In the CSF specimens investigated from multiple sclerosis patients, IgG yielded additional bands between $\mathrm{pH}$ 8.6-9.5 (Fig. 2). It is assumed that these bands constitute oligoclonal IgG. It has been shown that the number of bands varied between different multiple sclerosis patients in this $\mathrm{pH}$ region (Laurenzi and Link, 1979). The IgG pattern of the corresponding serum was found to be similar to that of normal serum. The CSF specimens from the neurosyphilis patient displayed an IgG pattern similar to that of multiple sclerosis.

$\beta$-trace protein migrated as one band at $\mathrm{pH} 8.0$ and one band at $\mathrm{pH} 8.4$ on immunofixation of CSF. In addition, one CSF pool and one multiple sclerosis specimen revealed one additional band between $\mathrm{pH}$ 7.4-7.5. No $\beta$-trace protein bands were demonstrable in the serum specimens investigated.

$\gamma$-trace protein migrated as one single, broad band at $\mathrm{pH}$ at or above 9.5 in all CSF specimens investigated. The serum specimens did not reveal any $\gamma$-trace protein.

\section{Discussion}

Most proteins yielded a complex band pattern when investigated by isoelectric focusing, which is consistent with the higher discriminative property and sensitivity of this method in comparison with, for example, conventional electrophoresis on agar gel or agarose gel. Immunofixation according to Arnaud et al. (1977), as carried out in the present study, gave results which were easily reproducible, and the method seems suitable and safe for characterisation of the migration of individual proteins on isoelectric focusing. This is essential if isoelectric focusing of CSF and serum is used for diagnostic purposes in neurology.

Stibler (1978) has investigated the mobility of individual normal CSF and serum proteins on isoelectric focusing using polyacrylamide gel plates which were made according to Kjellin and Vesterberg (1972), and subsequent crossed immunoelectrofocusing. This method involves cutting the polyacrylamide gel before identification of proteins. The data given by Stibler (1978) are difficult to interpret regarding migration of individual proteins. The differences in methodology and also differences in $\mathrm{pH}$ measurements may explain why the number and mobility of bands of individual proteins identified by Stibler differ from our results.

It is well established from characterisation of the mobility of transferrin on agar gel electrophoresis that this protein in CSF gives bands in addition to those in serum. The same is true for isoelectric focusing, as already pointed out by Stibler (1978).

Isoelectric focusing revealed a complex band pattern of IgG. The two multiple sclerosis patients included gave additional bands between $\mathrm{pH} 8.6$ and 9.5 , where IgG could not be demonstrated on investigation of normal CSF or serum. Therefore, isoelectric focusing may be regarded as a useful method for identification of oligoclonal IgG, provided that this $\mathrm{pH}$ region is examined. Oligoclonal IgG bands appearing in a $\mathrm{pH}$ region lower than 6.4 can not be distinguished from bands corresponding to other proteins.

The neurosyphilis patient yielded oligoclonal IgG bands in the same $\mathrm{pH}$ region as the multiple sclerosis patients when CSF was investigated. Thus, isoelectric focusing seems not to reveal any specific pattern of oligoclonal IgG bands in various types of inflammatory CNS disorders. This is also true for agar gel and agarose gel electrophoresis.

On isoelectric focusing IgA migrated in the same area as IgG and other proteins. $\operatorname{IgA}$ can, therefore, not be recognised by isoelectric focusing except when additional immunofixation is carried out. The mobility of oligoclonal $\mathrm{CSF} / \operatorname{IgA}$ on isoelectric focusing has not yet been investigated.

Oligoclonal IgM can be demonstrated in CSF in the form of sharp bands on agarose gel electrophoresis in acute aseptic meningitis (Frydén and Link, 1979) and in multiple sclerosis and neurosyphilis (unpublished observations). The two faint IgM bands observed on isoelectric focusing of CSF from the neurosyphilis patient migrated in an area where the bands can not be discriminated from those of, for example, IgG. Thus, isoelectric focusing is probably less suitable for identification of oligoclonal IgM bands, and probably also of oligoclonal $\operatorname{IgA}$ bands, unless subsequent immunofixation is carried out for correct identification of the immunoglobulin class.

This study was supported by the Swedish Medical Research Council (Project No. 3381) and the Swedish Institute by a scholarship to MAL. We thank Mrs Ingela Lilja for skilful technical assistance. 


\section{References}

Arnaud, P., Wilson, G. B., Koistinen, J., and Fudenberg, H. (1977). Immunofixation after electrofocusing: improved method for specific detection of serum proteins with determination of isoelectric points. I. Immunofixation print technique for detection of $\alpha_{1}$-protease inhibitor. Journal of Immunological Methods, 16, 221-231.

Delmotte, P. (1971). Gel isoelectric focusing of cerebrospinal fluid proteins. Zeitschrift für Klinische Chemie and Klinische Biochemie, 9, 334-336.

Delmotte, P. (1975). Etude par focalisation isoélectrique des gamma-globulines du liquide cephalo-rachidien dans la sclérose en plaques et d'autres maladies neurologiques. Université de Poitiers, YER Sciences Thèse no. 38.

Delmotte, P., and Gonsette, R. (1977). Biochemical findings in muliple sclerosis. Part 4 (Isoelectric focusing of the cerebrospinal fluid gammaglobulins in MS (262 cases) and other neurological diseases (272 cases)). Journal of Neurology, 215, 27-37.

Frydén, A., Link, H., and Norrby, E. (1978). CSF and serum immunoglobulin abnormalities and antibody titers in mumps meningitis and aseptic meningitis of other etiology. Infection and Immunity, 21, 852-861.

Frydén, A., and Link, H. (1979). Predominance of oligoclonal IgG type lambda in CSF in aseptic meningitis. Archives of Neurology (Chicago). In press.

Kjellin, K. G., and Vesterberg, O. (1972). Thin-layer isoelectric focusing of cerebrospinal proteins. A preliminary report with special reference to the diagnostic significance in multiple sclerosis. In Proceeding of the 20th Congress of Scandinavian Neurologists, Universitetsforlaget, Oslo, pp. 379380.

Kjellin, K. G., and Stibler, H. (1974). CSF-protein patterns in extra-pyramidal diseases. Preliminary report with special reference to the protein patterns in Huntington's chorea. European Neurology, 12, 186-194.

Kjellin, K. G., and Vesterberg, O. (1974). Isoelectric focusing of cerebrospinal fluid proteins in neurological diseases. Journal of the Neurological Sciences, 23, 199-213.

Kjellin, K. G., and Stibler, H. (1975). Cerebrospinal fluid protein patterns in spasmodic torticollis. European Neurology, 13, 461-475.

Kjellin, K. G., and Sidén, \&. (1977). Aberrant cerebrospinal fluid protein fractions found by electrofocusing in MS. European Neurology, 15, 40-50.

Latner, A. (1973). Some clinical biochemical aspects of isoelectric focusing. Annals of the New York Academy of Sciences, 209, 281-298.

Laurenzi, M. A., and Link, H. (1979). Comparison between agarose gel electrophoresis and isoelectric focusing of CSF for demonstration of oligoclonal immunoglobulin bands in neurological disorders. Acta Neurologica Scandinavica. In press.

Link, H., and Tibbling, G. (1977). Principles of albumin and $\mathrm{IgG}$ analyses in neurological disorders. II. Influence of serum concentration on CSF and evaluation of blood-brain barrier damage. Scandinavian Journal of Clinical and Laboratory Investigation, 37, 391-396.

Stibler, H. (1978). The normal cerebrospinal fluid proteins identified by means of thin-layer isoelectric focusing and crossed immunoelectrofocusing Journal of the Neurological Sciences, 36, 273-288.

Stibler, H., and Kjellin, K. G. (1976). Isoelectrio 을 focusing and electrophoresis of the CSF proteins in tremor of different origins. A study of 38 case with the cerebral syndrome of chronic alcoholism? Parkinson's disease and essential tremor. Journal of the Neurological Sciences, 30, 269-285.

Tibbling, G., Link, H., and Öhman, S. (1977). Principles of albumin and IgG analyses in neurological disorders. I. Establishment of reference values. Scandinavian Journal of Clinical and Laboratory Investigation, 37, 385-390. 